J. Clin. Chem. Clin. Biochem.

Vol. 20, 1982, pp. 621-626

\title{
Enzyme Immunoassay of Human Urinary Kallikrein
}

\section{Determination of human urinary kallikrein, $I I .^{1}$ )}

\author{
By $M$. Franke, S. Rohrschneider and $R$. Geiger
}

\begin{abstract}
Abteilung für Klinische Chemie und Klinische Biochemie (Leitung: Prof. Dr. H. Fritz) in der Chirurgischen Klinik Innenstadt der Universität München
\end{abstract}

(Received February 2/April 29, 1982)

Summary: An enzyme immunoassay for the determination of human urinary kallikrein has been developed and is compared with other human urinary kallikrein assays such as radioimmunoassay, dog blood pressure assay, rat uterus test after kinin liberation and synthetic substrate ${ }^{2}$ ) tests (AcPheArgOEt and S-2266). The usable range of the standard curve is from 0.05 to $12 \mathrm{ng}$ kallikrein per test. The intraassay coefficient of variation is between 2 and $4 \%$, the interassay coefficient of variation is between 4 and $12 \%$, and the recovery of authentic kallikrein added to urine samples is $95 \%$. Human saliva and human pancreatic kallikrein show the same binding curves as purified human urinary kallikrein. Kallikrein from urine of rats, dogs and rabbits as well as boar acrosin and pig pancreatic kallikrein, bovine trypsin and chymotrypsin show no cross-reactivity.

\section{Enzymimmunoassay für menschliches Härnkallikrein Bestimmung von menschlichem Harnkallikrein, III}

Zusammenfassung: Ein Enzymimmunoassay zur Bestimmung menschlichen Harnkallikreins wurde entwickelt und mit anderen Harnkallikrein-Bestimmungsmethoden wie Radioimmunoassay, Hundeblutdruck-Test, Rattenuterustest nach Kininfreisetzung und Aktivitätstest mit synthetischen Substraten ${ }^{2}$ ) (AcPheArgOEt und S-2266) verglichen. Der zur Bestimmung von Harnkällikrein verwendbare Bereich auf der Standardkurve lạg zwischen 0,05 und 12 ng pro Test. Der Intraassaykoeffizient lag zwischen 2 und 4\%, der Interassaykoeffizient zwischen 4 und 12\% und die Wiederfindungsrate von Harnkallikrein, das zu Harnenen zugegeben wurde, bei $95 \%$. Menschlicher Speichel und Pankreas-Kallikrein ergaben Bindungskurven, die mit der für reines Harnkallikrein erhaltenen Bindungskurve identisch waren. Kallikrein aus Harn von Ratten, Hunden und Kaninchen, Schweine=Akrosin und Schweinepankreas-Kallikrein sowie Trypsin und Chymotrypsin des Rindes zeigten keine Kreuzreaktion.

\section{Introduction}

Determination of tissue kallikrein (ËC 3.4.21.35) in humạn urine and body fluids is of special interest because of its postulated physiological role in kidney function and blood pressure regulation, fertilization processes, glucose metabolism and intestinal absorption $(1,2)$.

Various methods for the determination of urinary kallikrein are available at present. Some assays such as the biological assay (reduction of dog blood pressure after intravenous urine injection (3)) and the kininliberating test (kallikrein-induced kinin liberation from kininogens and determination of the kinins by biological assays, immunoassays or high performance liquid chromatography (4)) are cumbersome and not suitable for routine purposes. Other methods based on the hydro- lysis of synthetic substrates, e.g. $N^{\alpha}$-benzoyl-L-arginine ethyl ester, $N^{\alpha}$-tosyl- $L$-arginine methyl ester, AcPheArgOEt and S-2266 ${ }^{2}$ ) are often not specific and sensitive enough for kallikrein determination in tissue extracts or other body fluids. In addition, they do not allow the measurement of kallikrein in the presence of inhibitors i.e. in the form of the enzyme-inhibitor complex $(5-10)$.

\footnotetext{
1) $1 .=1 . c$. (23); II. = 1.c. (11)

2) Abbreviations:

AcPheArgOEt:

DValleuArgNHNp:

$N^{\alpha}$-acetyl- $L$-phenylalanyl- $L$-arginine ethyl ester

$D$-valyl- $L$-leucyl- $L$-arginine- $p$-nitroanilide ( $=\mathrm{S}-2266$ from $\mathrm{Kabi}$ )

ABTS 6-sulfonate)
} 
Recently, a radioimmunoassay has been developed for the determination of human urinary kallikrein (11) and since that time this assay has become a common method for the determination of human tissue kallikrein. However, general problems of the radioimmunoassay such as special and expensive equipment for radioactive measurements and the disposal of radioactive waste stimulated the development of alternative but also highly sensitive immunoassays. This report describes an enzyme immunoassay for human tissue kallikrein allowing estimation of kallikrein levels as low as $0.5 \mu \mathrm{g} / \mathrm{l}$ in a reasonably short time ( 5 hours incubation time).

\section{Material and Methods}

Human urinary kallikrein, used as a standard in the enzyme immunoassay, was purified as described (12). Human pancreatic kallikrein was isolated as described by Hofmann et al. (13). Horseradish peroxidase (EC 1.11.1.7; grade 1) and bovine trypsin and chymotrypsin were products of Boehringer, Mannheim. Boar acrosin was kindly provided by Müller-Esterl \& Fritz (14), human high molecular weight kininogen by Dittmann et al. (15)! Pig pancreatic kallikrein was a gift of Bayer AG, Wuppertal. Bovine serum albumin was purchased from Behringwerke AG, Marburg/Lahn. Bradykinin was a product of Bachem AG, Bubendorf, Switzerland. AcPheArgOEt ${ }^{2}$ ) was synthesized as described by Fiedler et al. (8). DValLeuArg$\mathrm{NHNp}^{2}$ ) was purchased from Kabi AB, Mölndal, Sweden. Tween 20 was a product of Serva AG. Microtiter plates M 129 B were purchased from Dynatech, Denkendorf, WestGermany.

Antibody production in rabbits was performed as described by Mann et al. (11). IgG fractions were isolated according to Steinbuch \& Audran (16).

Sample collection

24-hour urine samples of male and female healthy volunteers were collected. The urines were dialysed.against running water for $24 \mathrm{~h}$. Saliva obtained by selective catherization of the glandular duct was collected before and after oral administration of $2 \mathrm{ml}$ citric acid $(100 \mathrm{~g} / \mathrm{l})$, freeze-dried and stored at $-20^{\circ} \mathrm{C}$. Pancreatic juice was collected by a duodenal catheter in a X-ray monitored position. Samples of serum and seminal plasma were obtained from healthy volunteers.

Buffers

Buffer A $15 \mathrm{mmol} / 1 \mathrm{Na}_{2} \mathrm{CO}_{3}, 350 \mathrm{mmol} / \mathrm{I} \mathrm{NaHCO}_{3}$, $0.2 \mathrm{~g} / 1 \mathrm{NaN}_{3}, \mathrm{pH} 9.6$.

Buffer B $\quad 1.5 \mathrm{mmol} / 1 \mathrm{KH}_{2} \mathrm{PO}_{4}, 8 \mathrm{mmol} / 1 \mathrm{Na}_{2} \mathrm{HPO}_{4}$, $2.7 \mathrm{mmol} / \mathrm{l} \mathrm{KCl}, 150 \mathrm{mmol} / 1 \mathrm{NaCl}, 0.5 \mathrm{~g} / \mathrm{l}$, Tween 20, pH 7.4.

Buffer C $\quad 1.5 \mathrm{mmol} / 1 \mathrm{KH}_{2} \mathrm{PO}_{4}, 8 \mathrm{mmol} / 1 \mathrm{Na}_{2} \mathrm{HPO}_{4}$, $2.7 \mathrm{mmol} / \mathrm{l} \mathrm{KCl}, 150 \mathrm{mmol} / 1 \mathrm{NaCl}, 0.5 \mathrm{~g} / \mathrm{l}$ Tween $20,20 \mathrm{~g} / \mathrm{l}$ bovine serum albumin, $\mathrm{pH} 7.4$.

Buffer D $100 \mathrm{mmol} / \mathrm{l}$ citric acid, $100 \mathrm{mmol} / 1 \mathrm{~K}_{2} \mathrm{HPO}_{4}$, pH 4.0.

\section{Kallikrein activity}

Human kallikrein activity was measured using DValLeuArgNHNp and AcPheArgOEt as substrates (17). Kallikrein-induced kinin liberation from human urinary kallikrein by radioimmunoassay was performed according to Mann et al. (11).

\section{Biological assay}

Kinin activity was assayed by the rat uterus assay as described by Mann et al. (10). Bradykinin served as reference for kinin activity determination. Dog blood pressure assay was performed as described by Frey et al. (3).

\section{Coupling of peroxidase to IgG}

Preparation of peroxidase IgG conjugate was performed as described by Nakane \& Kawoi (18). After gel filtration on Sephadex G-100 the anti-human urinary kallikrein-IgG peroxidase conjugate was diluted 1:50 with buffer $C$ before being used for the enzyme immunoassay.

\section{Enzyme immunoassay conditions}

Microtiter plates were coated with the same anti-human urinary kallikrein-IgG solution (IgG $10 \mathrm{mg} / \mathrm{l}$ buffer) $(0.2 \mathrm{ml}$ per well) as used for the peroxidase $\mathrm{IgG}$ conjugate at $4{ }^{\circ} \mathrm{C}$ over night. The plates were then washed vigorously ( 3 times) in buffer $B$. Human urinary kallikrein standard samples and test samples were diluted with buffer $C$. Of these samples $0.2 \mathrm{ml}$ were added to the wells and the plates were incubated at $37^{\circ} \mathrm{C}$ for $3 \mathrm{~h}$ in order to bind the kallikrein to the solid-phase fixed antibodies. After incubation, the plates were washed ( 3 times) with buffer $\mathrm{B}, 0.2 \mathrm{ml}$ of the anti-human urinary kallikrein-IgG peroxidase conjugate was added to each well, and the plates were incubated again at $37^{\circ} \mathrm{C}$ for $2 \mathrm{~h}$. After washing peroxidase activity was measured as described by Anaokar et al. (19) by addition of $0.2 \mathrm{ml}$ working substrate solution (stock substrate consisted of $200 \mathrm{mg} \mathrm{ABTS}{ }^{2}$ ) dissolved in $10 \mathrm{ml}$ water). To prepare working substrate, $0.5 \mathrm{ml}$ stock soln. was added to $9.5 \mathrm{ml}$ buffer $\mathrm{D}$ and $0.2 \mathrm{ml} \mathrm{H} \mathrm{H}_{2} \mathrm{O}_{2}$ solution $\left(\mathrm{H}_{2} \mathrm{O}_{2}, 300 \mathrm{~g} / \mathrm{kg}\right.$, diluted $\left.0.6 \mathrm{ml} / \mathrm{l}\right)$ was added and the plates were incubated for $30 \mathrm{~min}$ at room temperature. Thereafter, the reaction was stopped by addition of $0.05 \mathrm{ml}$ sodium azide $(10 \mathrm{~g} / \mathrm{l})$. The absorption was read photometrically at $405 \mathrm{~nm}$ with a Microelisa ${ }^{\circledR}$-reader AM 115 from Dynatech, Denkendorf, West-Germany. Background generally ranged from $A_{405} \mathrm{~nm}=0.02$ to 0.08 . In each test a standard concentration curve with purified human urinary kallikrein was included. Standard curves were constructed by plotting the fraction of absorbance at $405 \mathrm{~nm}, \mathrm{~A}-\mathrm{N} / \mathrm{A}_{0}-\mathrm{N}$ (A: absorbance, $\mathrm{A}_{0}$ : maximal absorbance obtained with excess human urinary kallikrein, $\mathrm{N}$ : absorbance of the blank) against the dose of human urinary kallikrein in a logit-log mode or in a linear-log mode.

A scheme of the incubation conditions is shown in Table 1.

Tab. 1. Scheme of human urinary kallikrein (HUK) enzyme immunoassay. Samples were in triplicate.

\begin{tabular}{lll}
\hline & $\begin{array}{l}\text { Sample } \\
(\mathrm{ml})\end{array}$ & $\begin{array}{l}\text { Blank } \\
(\mathrm{ml})\end{array}$ \\
\hline Anti-HUK-IgG (10 mg/l) & $\begin{array}{l}0.20 \\
15 \mathrm{~h} \text { at } 4{ }^{\circ} \mathrm{C}\end{array}$ & 0.20 \\
Standard or sample & 0.20 & - \\
Buffer C & - & 0.20 \\
& $3 \mathrm{~h}$ at $37^{\circ} \mathrm{C}$ & \\
Anti-HUK-IgG peroxidase con- & 0.20 & 0.20 \\
jugate, dil. 1:50 & $2 \mathrm{~h} \mathrm{at} 37^{\circ} \mathrm{C}$ & \\
Substrate solution & 0.20 & 0.20 \\
& $30 \mathrm{~min}$ at $22^{\circ} \mathrm{C}$ \\
Sodium azide $(10 \mathrm{~g} / \mathrm{l})$ & 0.05 & 0.05 \\
& absorbance read at $405 \mathrm{~nm}$ \\
\hline
\end{tabular}

\section{Results}

\section{Concentration of the solid-phase IgG}

The least amount of IgG required to coat the microtiter plates was determined from standard curves of data obtained with plates treated with concentrations 


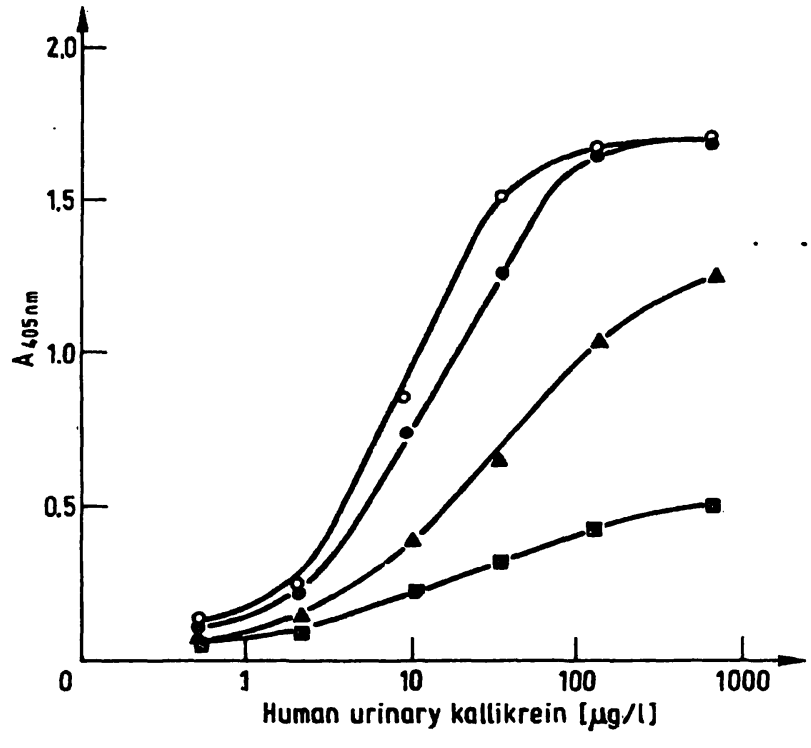

Fig. 1. Evaluation of the optimal concentration of the solidphase antibody. Dose response curves for human urinary kallikrein obtained with microtiter plate wells coated with $1 \mathrm{mg}(\bullet-\bullet), 2.5 \mathrm{mg}(\wedge-\wedge), 5 \mathrm{mg}(\bullet-\bullet)$ and $10 \mathrm{mg}(\mathrm{o}-0)$ of anti-human urinary kallikrein-IgG per liter.

of $\mathrm{IgG}$ ranging from 1 to $10 \mathrm{mg} / \mathrm{l}$. As seen in figure 1 , the standard curves were identical for IgG concentrations between 10 and $5 \mathrm{mg} / 1$ whereas standard curves obtained with IgG concentrations lower then $5 \mathrm{mg} / 1$ showed a decreased binding of human urinary kallikrein. Hence, we decided to use an IgG concentration of $10 \mathrm{mg} / 1$ for the assay. Anti-human urinary kallikreinIgG peroxidase conjugate dilution in the experiment was fixed at a 50-fold dilution.

\section{Anti-human urinary kallikrẹin-IğG peroxidase conjugate dilution}

The optimal dilution of the conjugate was determined from a standard curve obtained with microtiter plates coated with an IgG solution of $10 \mathrm{mg} / \mathrm{l}$ and conjugate diluted 100-, 50-, 20- and 10-föld with buffer $\mathrm{C}$. As the 50 -fold dilution was the highest dilution of the con- jugate at which optimal absorbance at $405 \mathrm{~nm}$ occurred, this conjugate dilution was chosen for the assay.

\section{Time and temperature dependence of the antigen anti-} body reactions

To determine the optimal incubation conditions for the enzyme immunoassay the time and temperature dependence of the first incubation, the binding of human urinary kallikrein to the solid-phase fixed antibody, was studied at 22 and $37^{\circ} \mathrm{C}$. The highest binding rate was observed at $37^{\circ} \mathrm{C}$, where equilibrium was reached after 3 hours (fig. 2a). The optimal time and temperature required for the second reaction, binding of antihuman urinary kallikrein-IgG peroxidase conjugate to solid-phase immunglobulin-fixed human urinary kallikrein, was similarily determined. As shown in figure $2 b$, this time equilibrium was reached after 2 hours at $37^{\circ} \mathrm{C}$. Concentration of the IgG-solution used for coating was $10 \mathrm{mg} / \mathrm{l}$, and the anti-human urinary kallikrein-IgG peroxidase conjugate dilution was 20 -fold.

\section{Standard curves and sensitivity}

The standard curve was consistently linear for human urinary kallikrein concentrations between 0.25 and $60 \mu \mathrm{g} / 1$ under routine conditions (fig. 3). The sensitivity of an enzyme immunoassay can be defined as "the smallest amount of antigen giving a response which is distinguishable from the response in the absence of antigen" (20). The lowest concentration of human urinary kallikrein that produced a response greater than that caused in the absence of human urinary kallikrein was $0.25 \mu \mathrm{g} / 1$, which corresponds to $50 \mathrm{pg}$ per well.

\section{Precision}

The intraassay coefficient of variation $(N=10)$ was $2-4 \%$ for human urinary kallikrein (range 0.25 to $64 \mu \mathrm{g} / 1)$. The interassay coefficient of variation of identical samples $(N=10)$ containing $1,4,16,64 \mu \mathrm{g} / 1$ was $4-12 \%$.
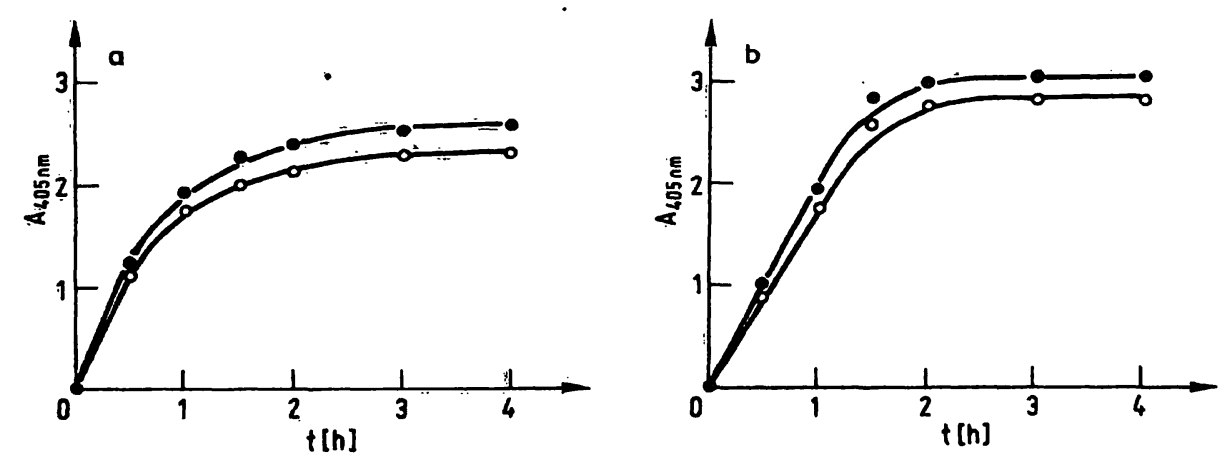

Fig. 2. Incubation time and temperature dependence of the first (a) and second (b) reaction. Dose response curves for human urinary kallikrein were obtained by incubating standard $(10 \mu \mathrm{g} / 1)$ at room temperature $(0)$ and $37^{\circ} \mathrm{C}(\bullet)$. 


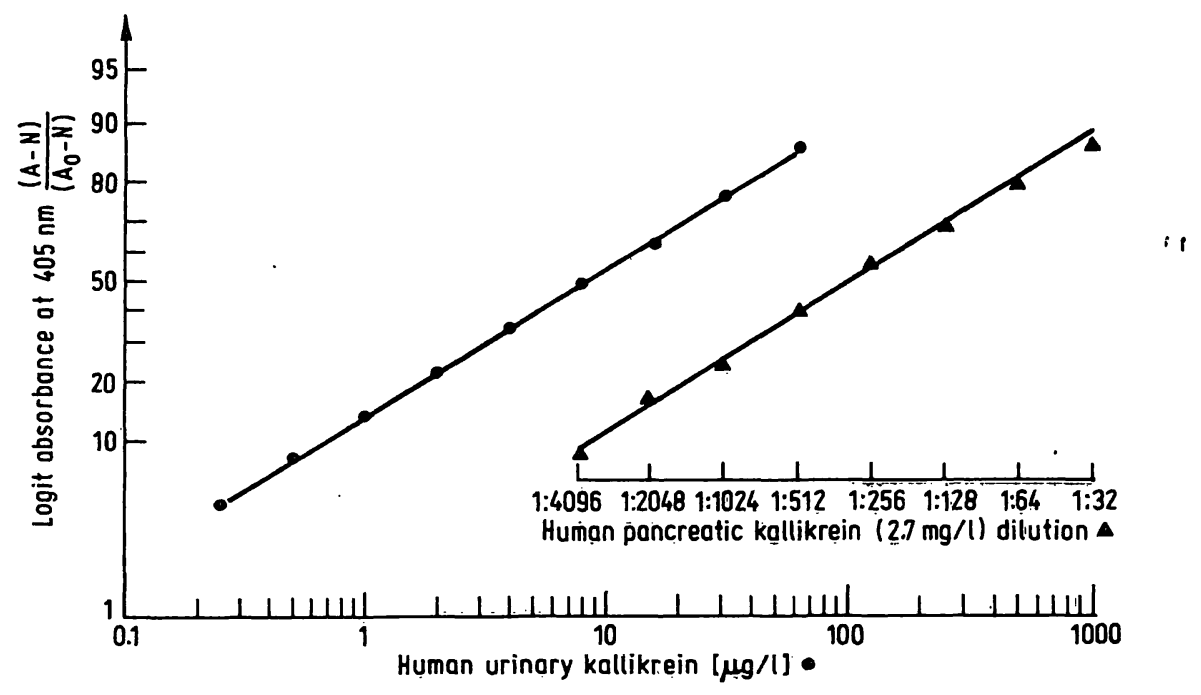

Fig. 3. Dose response curves of purified human urinary kallikrein and human pancreatic kallikriein in the hựman urininary kallikịein

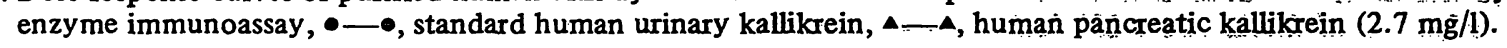

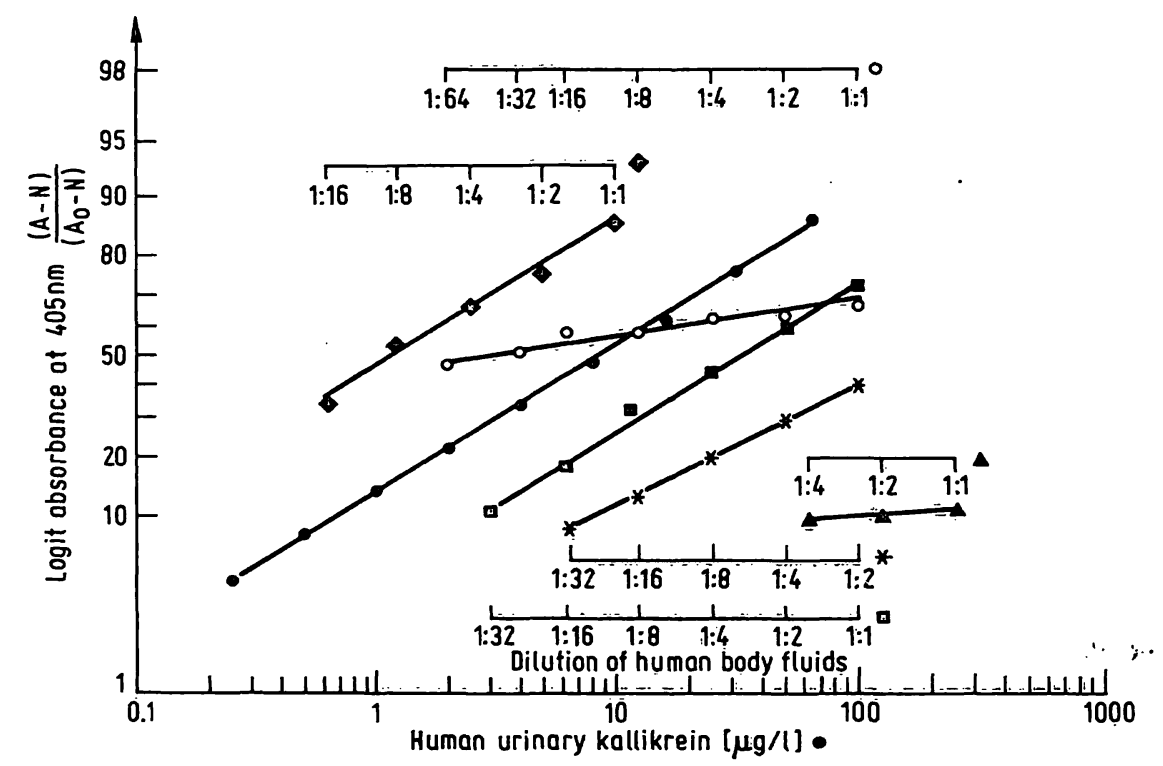

Fig. 4. Dose response curves of human urinary kallikrein and human body fluids in the hüman urinary kallikrein enzyme immuno-

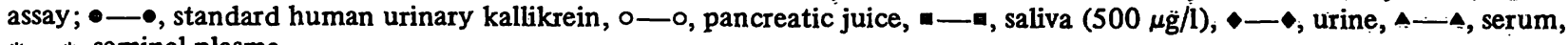
*-*, seminal plasma.

\section{Specificity}

Cross-reaction of other serine proteinases with antihuman urinary kallikrein-IgG was tested under the given immunoassay conditions. A cross-reaction was not observed with bovine trypsin and chymotrypsin, pig pancreatic kallikrein, boar acrosin and urine from rat, dog and rabbit. In the human samples investigated, immunologically active material was found in pancreatic juice, saliva, urine, serum and seminal plasma. Suitable dose-response curves are shown in figure 4.

\section{Rècovery test}

Recovery tests in which three different quantities of purified human urinary kallikrein were added to antigenfree rat urine showed a good precision of the assay. The data are listed in table 2 .
Tab. 2. Recovery test.

\begin{tabular}{llll}
\hline $\begin{array}{l}\text { Human urinary kallikrein } \\
\text { Added } \\
(\mu \mathrm{g} / \mathrm{l})\end{array}$ & $\begin{array}{l}\text { Recovered } \\
(\mu \mathrm{g} / \mathrm{l})\end{array}$ & $\mathrm{N}$ & $\begin{array}{l}\text { Recovery } \\
(\%)\end{array}$ \\
\hline 20 & $19.0 \pm 0.46$ & 10 & $95 \pm 2.3$ \\
10 & $10.5 \pm 0.12$ & 10 & $105 \pm 1.2$ \\
5 & $5.1 \pm 0.06$ & 10 & $102 \pm 1.2$ \\
\hline
\end{tabular}

Stability of the microtiter plates coated with antihuman urinary kallikrein-Ig $\dot{G}$

Microtiter plates coated with anti-human urinary kallikrein-IgG were air-dried and stored at $4{ }^{\circ} \mathrm{C}$ in sealed plastic bags containing silica gel. Identical standard curves were obtained under routine conditions within a period of 3 weeks after coating. Thereafter a decrease of binding was observed. 


\section{Comparison of the enzyme immunoassay with other methods}

In order to show the correlation of the enzyme immunoassay with other determination methods for human urinary kallikrein, 10 dialysed urine test samples were measured by different kallikrein assays. As can be seen from figure 5 the correlation coefficients of the synthetic substrate assays with AcPheArgOEt and DValLeuArgNHNp, the dog blood pressure assay, the kinin-liberation assay, the radioimmunoassay of human urinary kallikrein and the enzyme immunoassay are close to 1 .

Tab. 3. Comparison of the enzyme immunoassay for human urinary kallikrein with other assays for human urinary kallikrein. 10 samples of dialysed urine were measured by each method.

\begin{tabular}{ll}
\hline $\begin{array}{l}\text { Assays for } \\
\text { human urinary kallikrein }\end{array}$ & $\begin{array}{l}\text { Correlation coefficients } \\
\text { obtained with human urinary } \\
\text { kallikrein enzyme immuno- } \\
\text { assay }\end{array}$ \\
\hline Radioimmunoassay (11) & 0.9932 \\
Dog blood pressure (3) & 0.9643 \\
Kinin liberation (10) & 0.9824 \\
Synthetic substrates & 0.9910 \\
$\quad$ AcPheArgOEt (17) & 0.9920 \\
\hline
\end{tabular}

\section{Discussion}

The sensitive and specific enzyme immunoassay developed for human urinary kallikrein should be especially suitable for further studies on the physiological and pathophysiological role of tissue kallikreins. As the different tissue kallikreins in humans are immunologically indistinguishable (21), this asșay can be used to detect all of them.

The high specificy of the enzyme immunoassay could be demonstrated by employing various serine proteinases. Cross reactivity was not observed with bovine trypsin and chymotrypsin, boar acrosin and pig pancreatic källikrein. Furthermore, in analōgy to the results obtained by radioimmunoassay of human urinary kallikrein (11) we may expect that human proteinases other thän tissue kallikreins do not inter= fere in the enzyme immunoassay.

Dose response curves obtained with immunologically crosss-reacting material from pancreatic juice, serum and seminal plasma were not parallel with each other. These results are in agreement with data obtained using the radioimmunoassay for human urinary kallikrein (11), except for the binding curves for human pancreatic juice. This is of interest since purified human pancreatic kallikrein will give parallel curves in the enzyme immunoassay for human urinary kallikrein. Explanations for these interferences could be the presence of:
1) prokallikrein or modified kallikrein with immunologically different properties,

2) other, as yet uncharacterized, cross-reacting antigens, and

3) inhibitors in the samples which reduce binding to antibody due to kallikrein-inhibitor complex formation.

Further nonspecific interferences cannot be excluded at present. All these questions need to be further investigated and methods for the elimination interference must be developed.

A number of experiments were undertaken to compare the enzyme immunoassay with assays established already for the determination of human urinary kallikrein. For this purpose dialysed urine samples from 10 different persons were employed. The results obtained with the enzyme immunoassay were compared with those obtained by the dog blood pressure assay, a radioimmunoassay for human urinary kallikrein, a rat uterus assay after kallikrein-induced kinin liberation, and assays with AcPheArgOEt arid DValLeuArgNHNp as kallikrein substrates. The correlation between the synthetic substrate assays, the rat uterus assay after kallikrein-induced kinin liberation and the radioimmunoassay is more satisfactory than the correlation obtained by comparison of dog blood pressure assay and enzyme immunoassay. Though the correlation coefficient of the results of the enzyme immunoassay and the dog blood pressure assay is rather close to 1 , a considerable scattering of the data is observed. This is not too surprising, since the coefficient of variation of the blood pressure assay for kallikrein is approximately $20 \%$ (22). The excellent correlation, however between the two immunoassays indicates the high validity of the enzyme immunoassay.

Considerable advantages of the enzyme immunoassay over the radioimmunoassay are, among others, the lack of radiation hazards, greater stability of the label, higher throughput and ease of automation. The assay procedure is simple to perform in a relatively short time and requires only small quantities of kallikrein. The minimal detectable dose is $50 \mathrm{pg}$ per well. Therefore, this assay offers a precise and feasible test for human urinary kallikrein, which can be used as an alternative to the radioimmunoassay.

\section{Acknowledgement ,}

This work was supported by Deutsche Forschungsgemeinschaft, Sonderforschungsbereich 51, grant B-26. We wish to thank Prof. Dr. H. Fritz for many helpful discussions and comments during the work and for reading over the manuscript. We are indebted to Dr. Truscheit, Bayer AG, for the gift of porcine pancreatic kallikrein. We want to thank Prof. Dr. Schill for providing us with human seminal plasma. We are indebted to Dr. Lehnert for providing us with human pancreatic juice. 


\section{References}

1. Schachter, M. (1980) Pharmacol. Rev. 31, 1-17.

2. Geiger, R. (1981) in Proteinases and their Inhibitors (Turk, V. \& Vitale, Lj., eds.), Pergamon Press, Oxford, pp. 353-376.

3. Frey, E. K., Kraut, H. \& Werle, E. (1968) Das KallikreinKinin-System und seine Inhibitoren, Ferdinand Enke Verlag, Stuttgart.

4. Geiger, R. \& Fritz, H. (1981) Meth. Enzymol. 80, 466-493.

5. Trautschold, I., Werle, E. \& Schweitzer, G. (1974) in Methoden der enzymatischen Analyse (Bergmeyer, H. J. ed.) 3rd ed., pp. 1071-1080, Verlag Chemie, Weinheim/Bergstraße.

6. Moriwaki, C., Inone, N., Hoijma, Y. \& Moriya, H. (1971) Yakugaku Zasshi 91, 413-416.

7. Martin, C. J., Golubow, J. \& Axelrod, A. E. (1959) J. Biol. Chem. 234, 294-298.

8. Fiedler, F., Geiger, R., Hirschauer, C. \& Leysath, G. (1978) Hoppe-Seyler's Z. Physiol. Chem. 259, 1667-1673.

9. Claeson, G., Friberger, P., Knös, M. \& Erikson, E. (1978) Haemostasis 7, 76-78.

10. Mann, K., Geiger, R. \& Werle, E. (1976) Adv. Exp. Med. Biol. 70, 65-73.

11. Mann, K., Göring, W., Lipp, W., Keipert, B., Karl, H. J., Geiger, R. \& Fink, E. (1980) J. Clin. Chem. Clin. Biochem. $18,395-401$ :

12. Geiger, R., Stuckstedte, U. \& Fritz, H. (1980) HoppeSeyler's Z. Physiol. Chem. 361, 1003-1016.
13. Hofmann, W., Geiger, R. \& Fritz, H. (1982) Hoppe= Seyler's Z. Physiol. Chem. in press.

14. Müller-Ësterl, W., Kupfer, S. \& Fritz, H. (1980) HoppeSeyler's Z. Physiol. Chem. 361, 1811-1821.

15. Dittmann, B., Steger, A., Wimmer, R. \& Fritz, H. (1981) Hoppe-Seyler's Z. Physiol. Chem. 362, 919-927.

16. Steinbuch, M. \& Audran, R. (1969) Arch. Biochem. Biophys. 134, 279-284.

17. Geiger, R., Stuckstedte, Ü., Förg-Brey, B. \& Fink, E. (1979) Adv. Exp. Meḍ. Biol. 120A, 235-244.

18. Nakane, P. K. \& Kawaoi, A. (1974) J. Histochem. Cytochem. 22, 1084-1091.

19. Anaokar, S., Garry, P. J. \& Standefer, J. C. (1979) Clin. Chem. 25, 1426-1431.

20. Schuurs, A. H. W. M. \& Van Weemen, B. K. (1977) Clin. Chim. Acta 81, 1-40.

21. Fritz, H., Fiedler, F., Warwas, M., Truscheit, E., Kollb, H. J., Mair, G. \& Tschesche, H. (1977) in: Kininogenases - Kallikrein (Haberland, G. L., Rohen, J. W. \& Suzuki, T., eds.) Schattauer Verlag, Stuttgart-New York, pip. 15-28.

22. Arens, A. \& Haberland, G. L. (1973) in: Kininogenases Kallikrein (Haberland, G. L. \& Rohen, J. W., eds.) Schattauer Verlag, Stuttgart-New York, pp. 43-53.

23. Geiger, R., Mann, K. \& Bettels, T. (1977) J. Clin. Chem. Clin. Biochem. 15, 479-483.

Priv. Doz. Dr. Reinhard Geiger Abt. f. Klin. Chem. u. Klin. Biochemie Chiurg. Klin. Innenstadt d. Univiv. Nußbaumstr. 20 D-8000 München 2 